\title{
Land cover change and its impact on human-elephant conflict: a case from Fashiakhali forest reserve in Bangladesh
}

\author{
Mohammad Maruf Billah ${ }^{1}$ (D) Md. Masudur Rahman ${ }^{2}$ D $\cdot$ Joynal Abedin $^{2} \cdot$ Humaira Akter $^{2}$
}

Received: 23 July 2020 / Accepted: 4 May 2021

Published online: 19 May 2021

(c) The Author(s) 2021 OPEN

\begin{abstract}
Changes in land cover are a major driving force behind habitat change, which significantly impacts the distribution of wildlife and ecological systems. However, there is a substantial lack of information on the effects of land cover changes on wildlife habitat and local conservation. Therefore, it is essential to understand how land cover changes may threaten future land cover trends and wildlife habitat loss, especially in protected areas. Landsat satellite imagery uses a geographic information system and remote sensing techniques to determine the spatiotemporal pattern of land cover change and its impact on the human-elephant conflict in the Fashiakhali Wildlife Sanctuary. We found that within the sanctuary (1994-2005), settlements, agricultural land, and bare land increased by 69.8 ha (2.3\%), 991.6 ha (32.3\%), and 39.5 ha (1.3\%), and forest areas and water areas decreased by 1094.1 ha (35.7\%) and 6.9 ha $(0.2 \%)$, respectively. On the other hand (2005-2015), settlements, agricultural land, and water areas increased by $11.7 \mathrm{ha}(0.4 \%), 264.7 \mathrm{ha}(8.6 \%)$, and $36.2 \mathrm{ha}(1.2 \%)$, and forest areas and bare land decreased by 308.9 ha $(10.1 \%)$ and $3.7 \mathrm{ha}(0.1 \%)$, respectively. Our findings have shown that increased agriculture and settlements have become a severe threat to the ecological sustainability of elephant habitat, resulting in habitat fragmentation and human encroachment of elephant habitats, as well as extreme pressure and competition on resources.
\end{abstract}

Keywords Fashiakhali forest reserve · Bangladesh · Land cover change · GIS and RS · Human-elephant conflict

\section{Introduction}

The change in land use/land cover (LULC) is the rapid influence and response of human activities on nature, with significant consequences [1-4]. The rapid changes in land cover, especially in developing countries like Bangladesh, urban sprawl characterized by random and unplanned growth $[5,6]$, is one of the most anthropogenic causes of the loss of arable land [7-9], habitat destruction [10], and the decline in natural vegetation cover [11]. Besides, land cover changes due to agricultural growth and tourism industry [12], and the conversion of agricultural land into shrimp farming, has changed the soil properties [13], resulting in vegetation degradation and enormous environmental costs $[12,14]$. Local and or regional developments profoundly impact this form of transition-the ecosystem, potentially affecting the global environment.

Bangladesh has strong potential for reforestation as a tropical country that could support an expanded forest area. Since the 1870s, Bangladesh's forest area has declined [15], and the total forest land is less than $16 \%$ or 2.33 million ha [16]. Multiple variables have accounted for a significant deforestation rate ranging from 0.3 to $2 \%$ per year over the past 30 years and led to a wide area of degraded forests [17-20]. The world forest contains more than $80 \%$ of terrestrial biodiversity and plays a critical role

Mohammad Maruf Billah, mohammad.billah@northsouth.edu | 'Department of Environmental Science and Management, North South University, Dhaka, Bangladesh. ${ }^{2}$ Department of Geography and Environment, University of Dhaka, Dhaka, Bangladesh.

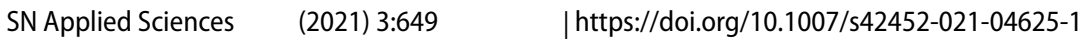


in maintaining ecological balance, environmental stability, and biodiversity conservation [21, 22]. Forest cover is a valuable resource for food supply and day-to-day storage; for example, an estimate shows that one million and more than one billion people produce a large part of their lives, such as income, energy, food, from the forest [23, 24]. Therefore, the wildlife corridor that passes through the forest is an essential part of the ecosystem's ecological integrity and long-term endurance [25]. However, forest reserves and wildlife habitats face destruction due to human pressures and settlements that exceed the forest resource's regenerative ability [26-28]. Besides, rising socioeconomic requirements and growing population impose stress on land use/land cover, resulting in unplanned and uncontrolled land use/land cover change $[29,30]$. At the local level, land use patterns and land cover changes contribute to systemic consequences, such as climate change, deforestation, land degradation, and environmental change [31-34]. Extensive effects on food security, biodiversity, and humans and communities' vulnerability have already been demonstrated globally [35]. Protected areas have already been designed globally and geographically distinguished and controlled according to the criteria and conservation aspects [36] to conserve the forest and its resources. The creation and management of protected areas depend on people's needs and welfare regarding wildlife's needs and sustainability. Indeed, the biodiversity conservation mechanism has changed quite a bit, notably in the realm of "people and nature," rather than in prior systems, which maintained an apparent dichotomy of the two [37]. Human-wildlife conflicts, however, do not exist in contrast to several other human-nature interactions happening concurrently within the system. The International Union for the Conservation of Nature (IUCN) declared that a human-wildlife conflict exists "when wildlife's requirements overlap with those of human populations, creating costs to residents and wild animals" [38]. This "overlap" may occur in urban and rural areas but is more common in and around protected areas, where wildlife population densities are generally higher [39].

The land cover characterizes the environmental condition and physical features of the land surface area such as water, crops, forests, human structures, shrubs, etc. [31, $40,41]$. Analysis of land use/cover change is an essential tool for estimating land cover changes at different spatial and temporal scales; for instance, it reveals the human behavior in a particular environment $[8,42,43]$. Remote sensing (RS) and Geographic Information System (GIS) may serve as a powerful tool to determine the spatial and temporal dynamics of land use/cover change [11, 44-47]. Scientists are now constantly using Remote Sensing (RS) and Geographic Information systems (GIS) on the broader aspect of land use/cover technology due to the massive development of satellite-based technologies [48-52]. In addition, the digital archive of remotely sensed data offers an outstanding opportunity to research historical land use/cover change [53]. Landsat satellite image can be a valuable and cost-effective data source with a spatial resolution of $30 \mathrm{~m}$ [34] to extract information from a given region and detect changes. Therefore, it is essential to evaluate the forest cover and consider the significant drivers for the change, deforestation, and forest cover degradation [54]. Recent reports have shown a decrease in forests of more than $9000 \mathrm{~km}^{2}$ during the 1930 s alone, with an annualized rate of deforestation reaching 1\% [15]. Most of the remaining areas degraded because of the intensive use for industry, firewood harvesting, and subsistence, including shifting cultivation in hill forests. Many experts differentiate between indirect and direct drivers, and even between degradation and those for deforestation. Indirect drivers were typically the same for deforestation and degradation, particularly poverty, overpopulation, and a community of drivers linked to ineffective governance, including lack of land use planning, corruption, weak management, enforcement power, and ambiguous land tenure. Besides, over-harvesting (excessive and illegal), agriculture or jhum (shifting cultivation), and encroachment (including industrial, military, and settlement) are the direct drivers for deforestation [15]. Nationally it is expected that fuelwood harvesting, excessive and illegal logging is responsible for forest degradation are the direct drivers.

Bangladesh is a deltaic country in terms of its unique geographical location, climate, and biodiversity-rich landforms. With a limited priority for protection and restoration, the forest reserve is poorly maintained for plants and animals. Consequently, protected areas with wildlife sanctuary are threatened $[55,56]$. The Fashiakhali forest reserve is essential for the ecosystem because of its protected areas, which are assumed to be acknowledged, devoted and managed, by legal or other efficient means to achieve the long-term conservation of nature through associated ecosystem services cultural or intellectual values [57]. Wildlife Sanctuary is an area preserved as an uninterrupted breeding ground for wild fauna. The habitat is sheltered for the inhabitants' constant well-being of migratory fauna [58]. The Fashiakhali Wildlife Sanctuary (FWS) is situated within the Fashiakhali forest range, famed for its Asian elephants (Elephas maximus), commonly referred to as a 'keystone' species bordered by 30 villages [59]. The increasing population in the Fashiakhali forest reserve needs to change land use and land cover pattern, which could potentially restore the ecological balance. In comparison, the legal and illegal overexploitation of forest resources makes the matter worse [56]. However, rising human-elephant conflict cases have been recorded 
in recent years, and habitat loss due to high population growth and poverty has proven to be the primary cause behind the situation [60]. The human-elephant conflict is alarming for elephants' conservation and protecting human life; for instance, damages of crops, social death, and elephant killing frequently appear $[61,62]$. Wild elephants are now protected by the Bangladesh Wildlife Conservation (Amendment) Act of 1974 and are prohibited from being hunted, killed, or captured. Under the act, the Chief Wildlife Warden can declare an elephant as a'rogue elephant' and issue a special permit to destroy it. The provisions of Wildlife Conservation Act (Draft) 2011, the sentence for killing an elephant shall be a prison of 2-7 years or a fine of Tk 100,000-1,000,000 (US\$ 1420-14,200) or both and a prison term and a fine of Tk 1,200,000 (US\$ $17,140)$ or both [63].

Several studies had been conducted in Bangladesh on the land cover changes and their impacts. For example, land cover change was assessed in the Chunati Wildlife Sanctuary (CWS) of Bangladesh using satellite imagery. The study found that the sanctuary had lost a significant amount of high-density forest cover [64]. Earlier, a survey of the Chunati Wildlife Sanctuary residents revealed that $49 \%$ were willing to conserve elephants, $16 \%$ were undecided, and 35\% were against their conservation [65]. Another survey indicates that 388 people in four conservation areas in the Teknaf Game Reserve, Chunati Wildlife Sanctuary, south-east, and north-east Bangladesh, about two-thirds claimed that a wild elephant protected area would not give benefit people, while the remaining acknowledge tourism value and significance of elephant conservation for biodiversity [66]. Another study used a geo-informatics approach to monitor the land-use change for forest fragmentation of Chunati Wildlife Sanctuary in Bangladesh demonstrated that forest fragmentation positively correlated with forest conversion nonforest uses [67]. Besides, land use significantly influences socio-economic and environmental structures' operation with the necessary concession for sustainability [68]. It is also demonstrated that the Chunati Wildlife Sanctuary has been exhibiting a shifting trend since the 1980s and recorded that the forest area has been turned into other land uses. However, there is no scientific monitoring of the forest cover in the Fashiakhali forest reserve area, which is critically important due to its surrounding protected area (Fashiakhali Wildlife Sanctuary). Therefore, this study intended to fill this gap and explore the land cover changes in the Fashiakhali forest reserve in Bangladesh.

The purpose of the study is to examine the spatial and temporal land-cover change in Fashiakhali wildlife sanctuary based on the Remote Sensing (RS) and Geographic Information System (GIS). This paper also explores the relationship between land cover changes on wildlife habitat and the destruction of human livelihood in the study area. The study focuses on evaluating the following hypotheses: (a) what were the significant changes in land cover in 1994, 2005, and 2015 in the Fashiakhali forest reserve? (b) if there is a relationship between land cover change and human-elephant conflict in the forest reserve areas. The results of this study will provide bases for assessing the sustainability and the management of the wildlife sanctuary and for taking actions to mitigate the degradation of the forest environment.

\section{Materials and methods}

\subsection{Study area}

Fashiakhali Wildlife Sanctuary (FWS) is a forest reserve located in Cox's Bazar district of Bangladesh. It lies between $90^{\circ} 3^{\prime} 36^{\prime \prime}$ E longitude and $21^{\circ} 43^{\prime} 53^{\prime \prime} \mathrm{N}$ latitude to $90^{\circ} 7^{\prime} 35^{\prime \prime} \mathrm{E} 21^{\circ} 4^{\prime} 51^{\prime \prime} \mathrm{N}$ and between $92^{\circ} 7^{\prime} 3^{\prime \prime} \mathrm{E} 21^{\circ}$ $44^{\prime} 27^{\prime \prime} \mathrm{N}$ to $92^{\circ} 6^{\prime} 6^{\prime \prime} \mathrm{E} 21^{\circ} 38^{\prime} 20^{\prime \prime} \mathrm{N}$ (Fig. 1). The Fashiakhali forest reserve covers an area of approximately 3068.7 ha consisting of the Fashiakhali forest beat. The range of Fashiakhali includes the Dulahazara forest beat under the Cox's Bazar North Forest Division. The study area's elevation ranges from $2 \mathrm{~m}$ (meter) to some areas exceeding $60 \mathrm{~m}$ in height. The geological structure of the forest reserve and the surrounding area are similar. This structure was built up 25 million years ago during the Pliocene era of the tertiary periods [69] consisting of the Dupitila series of sandstones and shale $[69,70]$. The study area experienced a moist tropical maritime climate with $740.8 \mathrm{~mm}$ mean annual rainfall where the average annual humidity is $79.3 \%$, and the mean annual temperature is $26.6^{\circ} \mathrm{C}$ [70]. Two forest villages with 112 populations were setting up in 1950; however, many Rohingya inhabitants have occupied the sanctuary later [71]. In 2007, it was declared a wildlife sanctuary under the Bangladesh Wildlife Preservation (Amendment) Act of 1947. However, the sanctuary now consists of around 8551 households bordered by 30 villages [59]. The total population of the Fashiakhali union (smallest administrative unit) is 18,945, where 9682 are males and 9263 are females with a population density of 1064 per $\mathrm{km}^{2}$ [72]. The area's literacy rate is meager, about $36.53 \%[72,73]$. The study area is undulating with numerous hill ranges of various heights that cover natural forest, plantation forest, deep bushy vegetation, low valleys, streams, and wetlands [69]. The vegetation of this area has been classified as a tropical rain forest [74]. The flora consists of the Gurjan forests (Dipterocarpus turbinatus) and the Dhakijam Syzygium species. Take plantation (Tectona grandis), the Eucalyptus species, and the Acacia species 


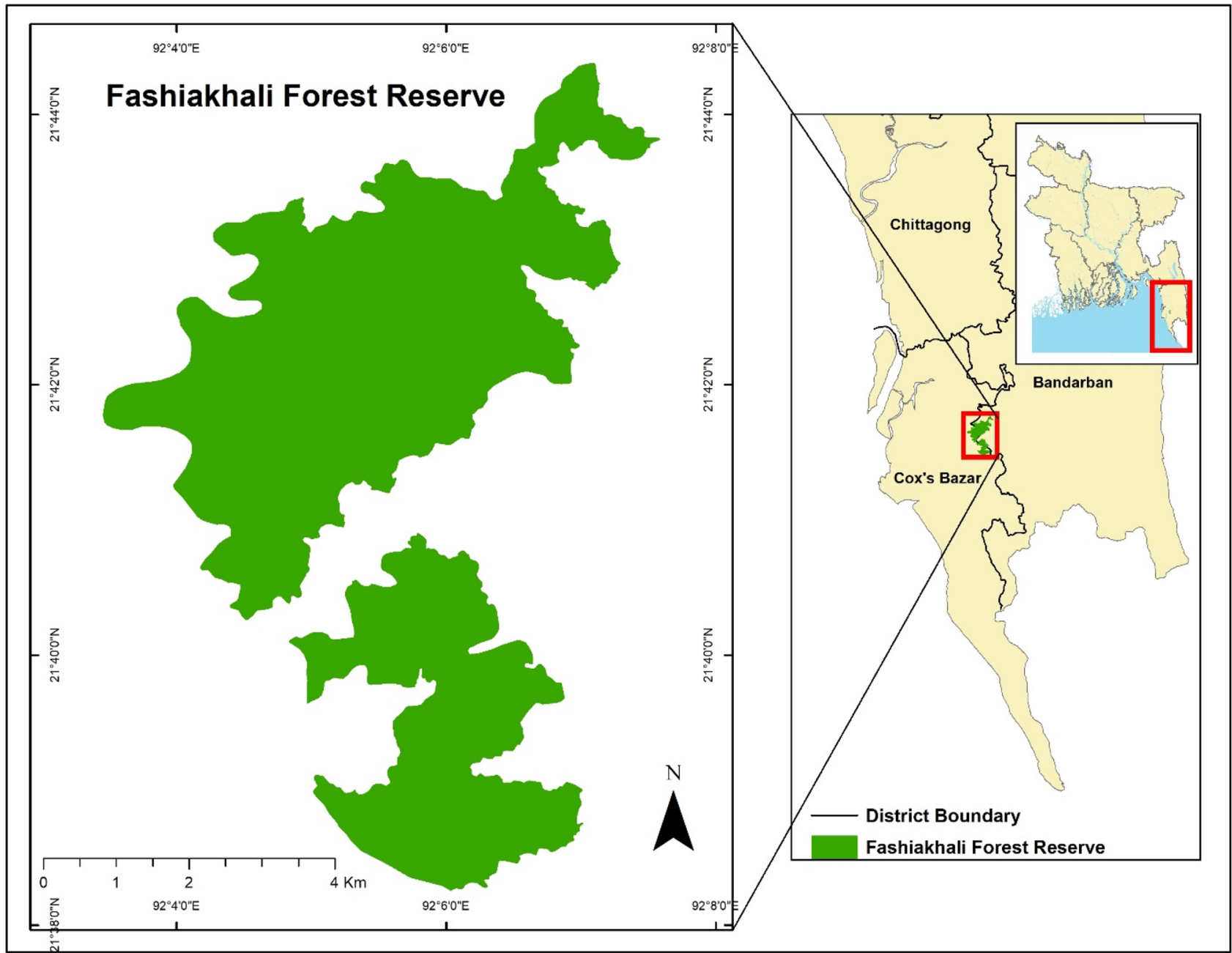

Fig. 1 Study area, Fashiakhali forest reserve, Cox's Bazar, Bangladesh

are present. This forest reserve is critically important for local biodiversity, especially one of the protected areas of Bangladesh Fashiakhali Wildlife Sanctuary is situated in this forest reserve [56]. The Fashiakhali Wildlife Sanctuary has a wide range of wildlife dependent on mixed evergreen forest, including a herd of Asian Elephants [59].

\subsection{Satellite image collection and field data}

The Landsat satellite images were obtained from the USGS Global Visualization Viewer (https://glovis.usgs.gov/). Landsat TM and Landsat OLI-TIRS (path 136, row 45) were used in this study (Table 1). Other data, e.g., the topographic map (scale: 1:25,000, sheet number: $84 C 2 C$, survey year: 2011) from the Survey of Bangladesh, elephant tracks (using GPS) from the field survey in the Fashiakhali forest reserve; location of human-elephant conflict data
Table 1 The characteristics of the Landsat data used in this study

\begin{tabular}{llllll}
\hline Satellite & Sensor & Path/row & $\begin{array}{l}\text { Spatial } \\
\text { resolution } \\
(\mathrm{m})\end{array}$ & $\begin{array}{l}\text { Date of } \\
\text { acquisition }\end{array}$ & Sources \\
\hline Landsat 5 & TM & $136 / 44$ & 30 & $13 / 12 / 1994$ & USGS \\
Landsat 5 & TM & $136 / 44$ & 30 & $10 / 02 / 2005$ & USGS \\
Landsat 8 & OLI-TIRS & $136 / 44$ & 30 & $22 / 02 / 2015$ & USGS \\
\hline
\end{tabular}

was collected from field surveys by random sampling techniques.

\subsection{Image processing}

Remote sensing data has emerged as one of the most prominent data sources for quantitatively, spatially, and temporally monitoring land-cover change [75-77]. Evaluating the spatial and temporal change in land cover in the 
Fashiakhali forest reserve, three Landsat imageries were used and processed by the remote sensing image processing software ENVI 5.3 (Harris Geospatial, Colorado, USA), ERDAS IMAGINE 2014 (Hexagon Geospatial, Madison, US) and ArcGIS 10.3 (ESRI, California, USA). We considered the study area's climate pattern, particularly the monsoon's influence on the image's spatial signature, satellite imagery captured during the dry season between December and February (winter) as less than 10\% cloud cover. Open access remote sensing data remains unsystematic error; atmospheric and geometric correction is therefore needed. A relatively high-resolution image from Landsat 8 (sensors: OLI-TIRS) was geo-referenced using ArcGIS 10.3 and ERDAS IMAGINE 2014 software. Other Landsat images were co-registered to perform the geometric correction to the geo-referenced OLI-TIRS image as a reference. In the rectification process, we used about 60 ground control points (GCPs) in the study. Dispersed GCPs yielded a root mean square error (RMSE), which was not more than 0.45 pixels. Later, we performed atmospheric correction for all satellite images in ENVI 5.3. A first-order polynomial fit was applied and used the nearest neighbor method and then resampled to $30 \mathrm{~m}$ pixel size. The Bangladesh Transverse Mercator System (BTM), an area-specific standard UTM projection system for Bangladesh, has been applied as the coordinate system [78]. The spectral information sensed by each Landsat- 5 TM sensor is stored as an 8-bit digital number (DN) [79] and Landsat-8 OLI-TIRS sensor as a 16-bit DN with 12-bit radiometric resolution [80] in the L1T and L1G products. DNs of each scene were converted to top of atmospheric (TOA) spectral radiance following equations (Eq) adopted by [81] and USGS (Eq. 1 TM images, Eq. 2 OLITIRS image) using sensor-specific calibration parameters derived from the image L1T and L1G metadata file. The radiance of each scene's reflective bands was then converted to the TOA reflectance using the standard equations (Eq. 3 for TM images, Eq. 4 for OLI-TIRS image) formulated by [82] and USGS.

$$
L_{\lambda}=\frac{\left(L_{\text {max }}-L_{\text {min }}\right)}{\left(\mathrm{QCAL}_{\max }-\mathrm{QCAL} L_{\text {min }}\right)} *\left(\mathrm{QCAL}-\mathrm{QCAL_{ \text {min } }}\right)+L_{\text {min }}
$$$$
L_{\lambda}=\frac{M_{\mathrm{L}} * \mathrm{QCAL}+A_{\mathrm{L}}}{\Pi * L_{\lambda} * d^{2}}
$$

$p_{\lambda}=\operatorname{ESUN}_{\lambda} * \cos \theta_{s}$

$p_{\lambda}=M_{\mathrm{p}} * \mathrm{QCAL}+A_{p}$

In the above equations, $L_{\lambda}$ is the TOA spectral radiance $\left(\mathrm{W} \mathrm{m} \mathrm{m}^{-2} \mathrm{sr}^{-1} \mu \mathrm{m}^{-1}\right), \mathrm{QCAL} \mathrm{L}_{\max }$ and $\mathrm{QCAL}_{\text {min }}$ are maximum and minimum quantized calibrated pixel values typically as 255 and 1, QCAL is the DN values, $L_{\max }$ and $L_{\min }$ are spectral radiances scaled to $Q C A L_{\max }$ and $\mathrm{QCAL}_{\min }, M_{\mathrm{L}}$ and $A_{\llcorner}$are band-specific multiplicative and additive radiance rescaling factors obtained from the image L1T and L1G metadata file, $P_{\lambda}$ is the unitless TOA reflectance, $d$ is the earth-sun distance in astronomical units, $\mathrm{ESUN}_{\lambda}$ is the mean solar exoatmospheric irradiances $\left(\mathrm{W} \mathrm{m}^{-2} \mu \mathrm{m}^{-1}\right.$ ), $\cos \theta_{\mathrm{s}}$ is the solar zenith angle (radians) calculated from the solar elevation angle stored in the image L1T and L1G metadata file, $P_{\lambda}$ is the TOA spectral reflectance, $M_{\mathrm{p}}$ and $A_{\mathrm{p}}$ are band-specific multiplicative and additive reflectance rescaling factors obtained from the image $L 1 T$ and $L 1 G$ metadata file. The ESUN ${ }_{\lambda}$ and $d$ values were applied from [81].

\subsection{Image classification scheme and algorithms}

Land use/cover thematic mapping is often done using a variety of image classification techniques [83]. To assess the Fashiakhali forest reserve's land cover changes, we used a moderation of the Anderson scheme Level-I method [84]. Before classifying the land cover, all satellite data was revised to obtain the digital numbers (DNs) of different land cover categories using spectral and spatial profiles. The classification scheme was established based on ancillary information from a field survey conducted in 2015 in the Fashiakhali forest reserve, visual image interpretation, and local knowledge of the study area. Five land cover types-settlement, water, agriculture/grassland, forest, and bare land were classified. The description of each category of land cover considered in this study is shown in Table 2. In our land cover classified scheme, we assimilated the agricultural land and grassland into a single class because during the dry season in Bangladesh, due to scarcity of rainfall, no agricultural crop is cultivated and huge amount of agricultural land is likely to reduce and is converted into grassland $[85,86]$.

As the accuracy in land cover classification is fundamentally significant for remote sensing analysis, several studies evaluated the support vector machine (SVM), maximum likelihood classifier (MLC), decision tree (DT), and ensembles classifier such as Random Forest (RF) for monitoring land-cover change and these algorithms have shown a quantum increase in current times [87]. In particular, SVM [88] and Random Forest [89] have recently received considerable attention in remote sensing image classification, RF have been applied relatively extensively, offer suitable levels of accuracy $[90,91]$, and both are supervised, nonparametric statistical learning techniques [92, 93]. However, the images of the study were classified using a supervised maximum likelihood classification (MLC) algorithm [90], and the most practical algorithms for parametric classification rule $[75,94,95]$ usually been proven to achieve 
Table 2 Land cover classification scheme

\begin{tabular}{ll}
\hline Class & Description \\
\hline Settlement & Residential, commercial, transportation, industrial, utilities, mixed and other urban \\
Water & Rivers, ponds, reservoirs \\
Agriculture/grassland & Cropland, herb, and shrub \\
Forest & High vegetation, mixed forest lands, reserved forest, non-reserved forests, settle- \\
& ment under tree cover, homestead vegetation \\
Bare land & Fallow land, exposed soils, bare soil \\
\hline
\end{tabular}

the best results if each class of the remotely sensed data has a Gaussian distribution $[11,96]$. MLC is self-evident and still used because this algorithm significantly decreases the data necessities and providing a potential to extract comprehensive information [87, 97-99]. Based on the visual analysis of the locations on Google Earth and the image itself, 50 polygons were digitized for each category.

\subsection{Change detection and accuracy assessment}

The change detection and the classified maps have been produced using the pixel-by-pixel method [100]. In the classified land cover images derived from the MLC algorithm, some technical errors were found between the agriculture and forest due to their similar spectral features. Next, to recover the classification's accuracy, a simple and efficient method called post-classification refinement was used $[11,101,102]$. Then, to remove the salt-and-pepper effect on the classified land covers, a $3 * 3$ majority filter was applied [103]. After that, to determine the land cover changes, a post comparison of changes was executed [5, $11,102,104]$.

For the accuracy assessment of this study's land cover classification, field data, topographic maps, and geographical features on land cover maps were used. To assess the accuracy of land cover maps obtained from Landsat data, a total of 225 stratified random sample points (i.e., 45 for each class) for 1994, 2005, and 2015 land cover maps were selected. For the accuracy evaluation of the 2015 land cover map, a high-resolution Google earth image was also used. To calculate the classification precision, a nonparametric Kappa test following the equation (Eq. 5) was performed [11, 105].

$K=\frac{N \sum_{i-1}^{r} X_{i i}-\sum_{i-1}^{r}\left(x_{i+}\right)\left(x_{+i}\right)}{N^{2}-\sum_{i-1}^{r}\left(x_{i+}\right)\left(x_{+i}\right)}$

where $r$ is the row number in the matrix, is the number of observations in row- $i$ and column- $i$ (the diagonal elements), + and + are the marginal totals of row- $r$ and column-i, respectively, and $N$ is the number of the observations.

\section{SN Applied Sciences}

\subsection{Human-elephant conflict risk hot spot}

The elephant's routes and their movement throughout the study areas were observed and identified by any elephant signs (e.g., footprints, dungs, and broken trees) were recorded on GPS. The plotted GPS data of elephant signs revealed the elephant movement routes, corridor, and entry point to settlement or crop fields. In the survey process, local people were guided to find the elephant routes accurately. Here two crucial pieces of evidence or features that precisely locate elephants' presence are elephant's footprints and dung piles. The human-elephant conflict (HEC) zone and elephant hot spots were visualized in the map (Figs. 5, 7) using ArcGIS10.3 software. The risk hot spot map is derived from Kernel density estimation and hot spot mapping. The data includes information on the households' location affected and damaged, e.g., homestead garden agricultural field, and social death. From the respondents' interviews, the participants were asked to name and locate the areas where most conflicts occur within the study areas.

\section{Results}

\subsection{Accuracy assessment}

We found the total accuracy of the Landsat-derived classified images was $95 \%, 92 \%$, and $96 \%$, with the result of kappa coefficient of about $0.90,0.86$, and 0.93 for 1994, 2005 , and 2015 respectively (Table 3 ). The product is similar to the standard land cover mapping accuracy of $85-90 \%$, as suggested [84].

This study's accuracy assessment confirmed an accuracy level is closer to another survey conducted in nearby regions for forest cover change in Teknaf in Bangladesh for the years 2016/2017 [106]. That study obtained an overall classification accuracy of 94.53 and $95.14 \%$ for 2016 and 2017 land cover maps, respectively, with general Kappa statistics of 0.93 and 0.94 . The producer and user accuracy 
Table 3 Overall accuracy and kappa coefficient of land cover classification

\begin{tabular}{llllll}
\hline Year & Class & User accuracy & $\begin{array}{l}\text { Producer } \\
\text { accuracy }\end{array}$ & $\begin{array}{l}\text { Overall accu- } \\
\text { racy }\end{array}$ & $\begin{array}{l}\text { Kappa } \\
\text { coeffi- } \\
\text { cient }\end{array}$ \\
\hline 1994 & Settlement & 76 & 81 & 95 & 0.90 \\
& Agriculture/grassland & 86 & 90 & \\
& Forest & 93 & 88 & \\
& Water & 80 & 100 & \\
& Bare land & 91 & 71 & \\
& Settlement & 91 & 76 & \\
& Agriculture/grassland & 78 & 82 & \\
& Forest & 73 & 79 & \\
& Water & 100 & 100 & \\
& Bare land & 73 & 54 & \\
& Settlement & Agriculture/grassland & 88 & 93 & \\
& Forest & 89 & 88 & \\
& Water & 100 & 87 & \\
& Bare land & 91 & 100 & \\
\hline
\end{tabular}

for forest cover ranged between 92.98 and $98.21 \%$ and $96.49-92.98 \%$, respectively.

\subsection{Land cover classification}

The land cover classification results are summarized for 1994, 2005, and 2015 in Table 4 and the land cover classification is represented in Fig. 2. From 1994 to 2005, settlement, agricultural areas, and bare land increased by 69.8 ha $(2.3 \%), 991.6$ ha $(32.3 \%)$, and 39.5 ha $(1.3 \%)$, respectively, but forest areas and water areas and decreased by 1094.1 ha (35.7\%) and 6.9 ha $(0.2 \%)$, respectively. From 2005 to 2015, settlement, agricultural areas, and water areas increased by 11.7 ha $(0.4 \%)$, 264.7 ha $(8.6 \%)$, and 36.2 ha (1.2\%), respectively. Besides, land forest areas and bare land decreased by 308.9 ha $(10.1 \%)$ and 3.7 ha $(0.1 \%)$, respectively.

Therefore, the total amount of decreased forest areas is 1402.9 ha from 2006.4 ha (1994) to 603.5 ha (2015), which is $45.7 \%$ of the total areas of land. The changes in forested areas over time are meant by the changes in wildlife movement in 21 years. As shown in Table 5, the areas well qualified for agriculture or grassland area was 582.2 ha in 1994; this number increased by $40.9 \%$ and became 1838.5 ha in 2015 . These given data (Table 5) expressly state that the increase in agricultural areas/ grassland mostly results in deforestation, which means some forest areas were removed and converted into household agriculture. The transitions of land cover types are represented in Fig. 3.
Table 4 Summary of Landsat classification area statistics for 1994, 2005, and 2015

\begin{tabular}{|c|c|c|c|c|c|c|}
\hline \multirow[t]{2}{*}{ Land cover types } & \multicolumn{2}{|l|}{1994} & \multicolumn{2}{|l|}{2005} & \multicolumn{2}{|l|}{2015} \\
\hline & Area (ha) & $\%$ & Area (ha) & $\%$ & Area (ha) & $\%$ \\
\hline Settlement & 37.7 & 1.2 & 107.6 & 3.5 & 119.3 & 3.9 \\
\hline Agriculture/grassland & 582.2 & 19.0 & 1573.8 & 51.3 & 1838.5 & 59.9 \\
\hline Forest & 2006.4 & 65.4 & 912.3 & 29.7 & 603.5 & 19.7 \\
\hline Water & 94.2 & 3.1 & 87.3 & 2.8 & 123.5 & 4.0 \\
\hline Bare land & 348.1 & 11.3 & 387.6 & 12.6 & 383.9 & 12.5 \\
\hline Total & 3068.7 & 100.0 & 3068.7 & 100.0 & 3068.7 & 100.0 \\
\hline
\end{tabular}




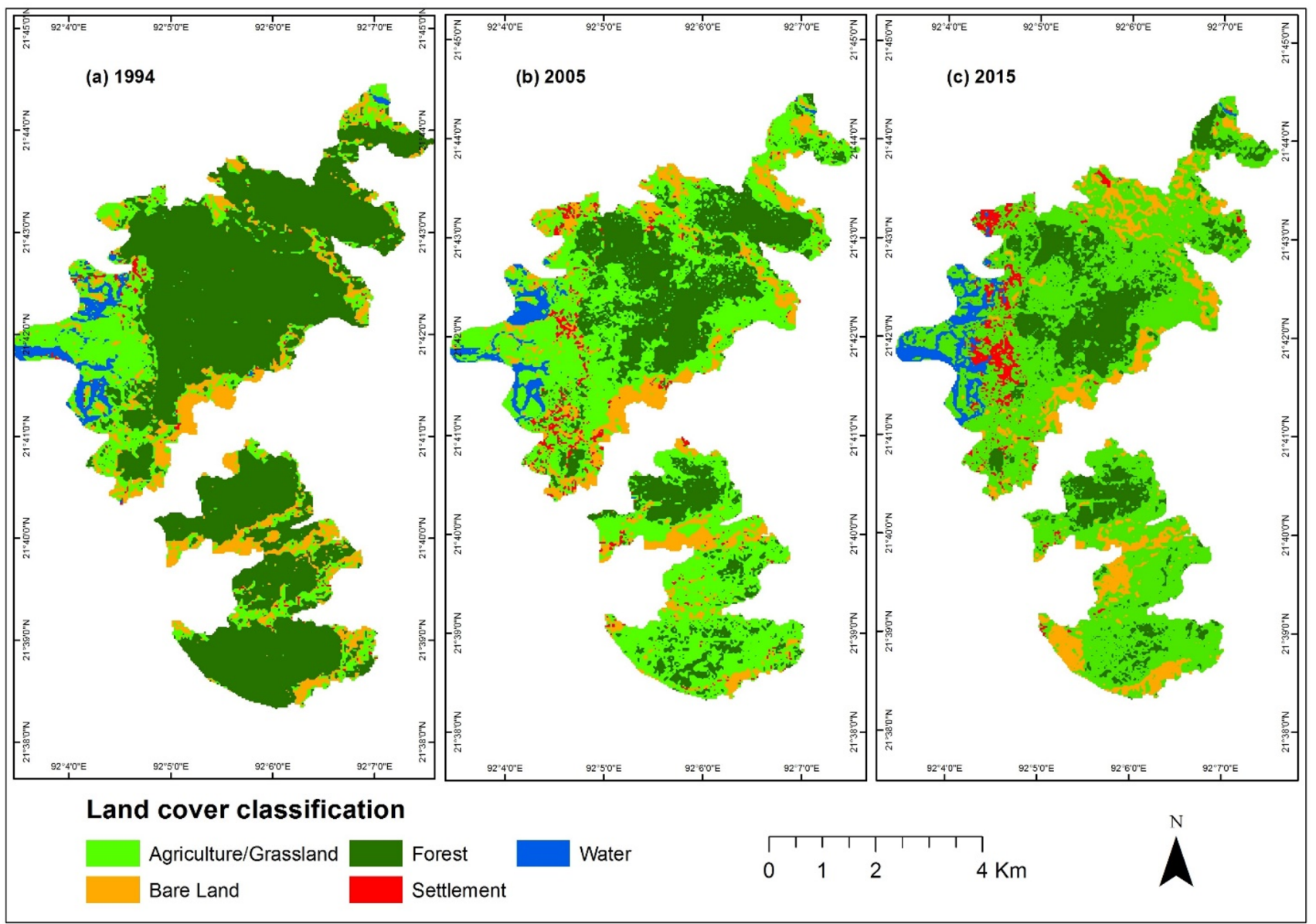

Fig. 2 Land cover classification of Fashiakhali forest reserve

Table 5 Relative changes of land cover types from 1994 to 2015

\begin{tabular}{|c|c|c|c|c|c|c|}
\hline \multirow[t]{3}{*}{ Land cover types } & \multicolumn{6}{|c|}{ Relative changes } \\
\hline & \multicolumn{2}{|c|}{ 1994-2005 } & \multicolumn{2}{|c|}{ 2005-2015 } & \multicolumn{2}{|c|}{ 1994-2015 } \\
\hline & Area (ha) & $\%$ & Area (ha) & $\%$ & Area (ha) & $\%$ \\
\hline Settlement & 69.8 & 2.3 & 11.7 & 0.4 & 81.5 & 2.7 \\
\hline Agriculture/grassland & 991.6 & 32.3 & 264.7 & 8.6 & 1256.3 & 40.9 \\
\hline Forest & -1094.1 & -35.7 & -308.9 & -10.1 & -1402.9 & -45.7 \\
\hline Water & -6.9 & -0.2 & 36.2 & 1.2 & 29.3 & 1.0 \\
\hline Bare land & 39.5 & 1.3 & -3.7 & -0.1 & 35.8 & 1.2 \\
\hline
\end{tabular}

*Note: (-) sign indicates a decrease of change 
Percent (\%) of Land Cover Transition

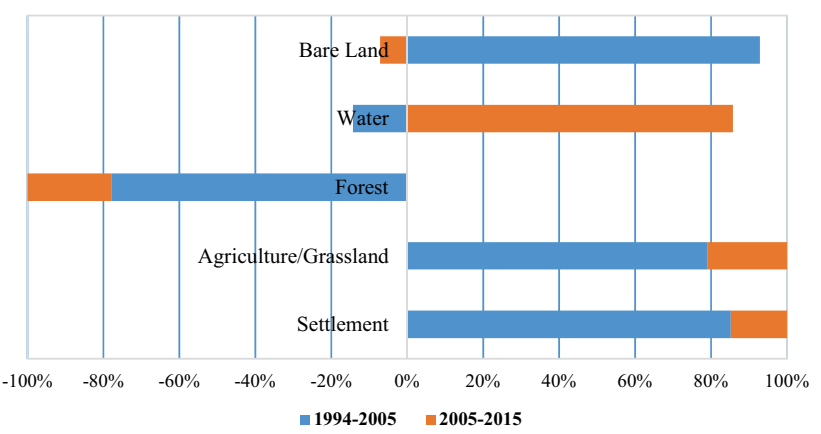

Fig. 3 Transition of land cover types

Table 6 Significant land cover transitions from 1994 to 2015

\begin{tabular}{llll}
\hline From class & $\begin{array}{l}1994-2005 \\
\text { area (ha) }\end{array}$ & $\begin{array}{l}\text { 2005-2015 } \\
\text { area (ha) }\end{array}$ & To class \\
\hline Settlement & 22.7 & 38.9 & Agriculture \\
Agriculture/grassland & 58 & 278.4 & Settlement \\
& 20.2 & 68.3 & Water \\
Forest & 124.7 & 230.3 & Bare land \\
& 1132.4 & 363.2 & Agriculture \\
Water & 45.3 & 38.6 & Settlement \\
Bare land & 73.1 & 42.2 & Bare land \\
& 28.4 & 10 & Agriculture \\
No Change & 151 & 111 & Agriculture \\
\hline
\end{tabular}

\subsection{Land cover change detection}

The change detection analysis for each land cover is summarized in Table 6; Fig. 4. Significant transitions between 1994 and 2015 are found, particularly the conversion from forest to agricultural land shows a remarkable change from 1994 to 2005 (1132.4 ha) and between 2005 and 2015 (363.2 ha). The increased agricultural activity that replaced the forested areas indicated the human necessity for alternative food production, e.g., small vegetation adjacent to the household. Significant changes have been seen in agriculture to bare land in both periods 1994-2005 (124.7 ha) and 2005-2015 (230.3 ha).

\subsection{Land cover and forest change impacts on human-elephant conflict}

The survey was taken in 2015 (Fig. 5) shows the wild elephant route distribution and depicts the number of respondents who observed the conflict between human livelihood and wildlife (e.g., elephant) and shared their experiences from recent to past few years. We conducted 50 interviews with the village households adjacent to the Fashiakhali forest range. Villagers were asked in these villages if they thought the human-elephant conflict was increasing in the area, and $98 \%$ of respondents thought it was for several types of damages they observed. $82 \%$ of village people mentioned that they were affected by elephants and destroyed their fields'fences and crops. Wild elephant route distribution and their proximity to human settlement are represented in Fig. 5.

\subsection{Human-elephant conflict risk hot spot}

We used the human-elephant conflict data collected through field surveys in Fashiakhali forest reserve areas in 2015. The participants were asked to name and locate the places where most conflicts occur within the study areas from the respondents' interviews. The sites were marked and located on a map of human-elephant conflicts (Fig. 7). The map shows the human-elephant conflicts hot spots (or areas where a lot of conflicts occur). The hot spots are located inside the Fashiakhali forest reserve and Fashiakhali Wildlife Sanctuary. Our survey found out that $82 \%$ of the respondents claimed that the conflict areas were the household's adjacent agricultural fields (Fig. 6).

\section{Discussion}

\subsection{Land cover classification}

Based on the classification of multiple temporal satellite imageries, our study's findings revealed significant differences in different land cover types over different years, particularly the enormous changes and differences among the forest cover areas. The obtained data from our findings and Landsat image classification expressly state that the increase in agricultural areas/grassland mostly results in deforestation, which means some forest areas were removed and might be converted to household agriculture. The causes might be attributed to a lack of frequent surveillance by the forest department and substantial encroachment and rapid destruction of a natural resource from Fashiakhali. There are 16 villages inside the sanctuary with 3300 people are highly reliant on their subsistence services. Rohingya refugees have already occupied a substantial portion of the forest resource, and their illegal logging is simultaneously responsible for the land-use change in Fashiakhali [59, 71]. Like our study area, the land cover change of Chunati Wildlife Sanctuary in Chittagong in Bangladesh was analyzed. They showed nearly $76 \%$ of the total land area ( $8258 \mathrm{ha}$ ) was covered by vegetation during 2005; and reduced to $61 \%$ (6637 ha) in 2015, $15 \%$ declined from 2005, and vacant land coverage increased from nearly 


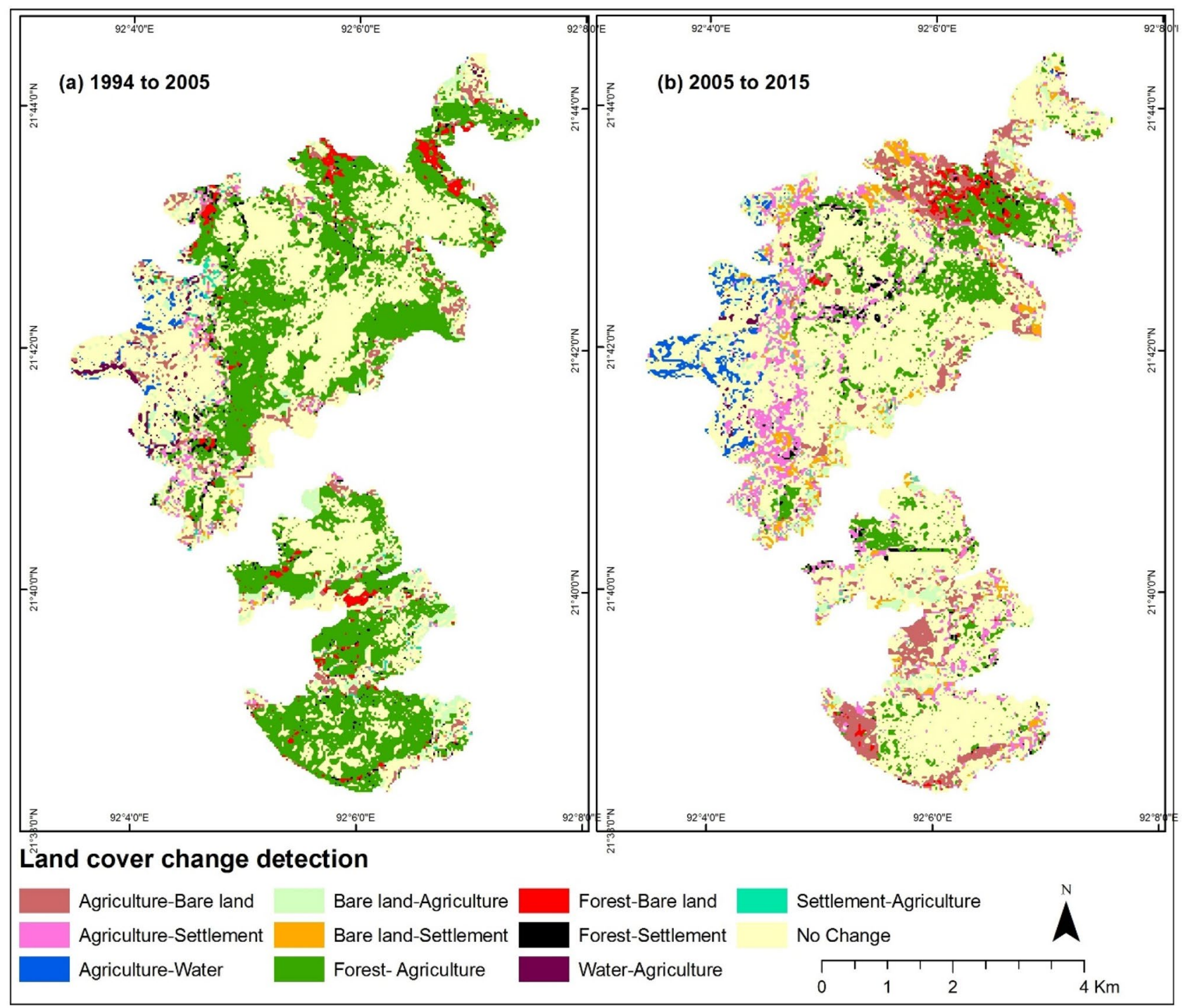

Fig. 4 Land cover change detection of Fashiakhali forest reserve

$10 \%$ in 2005 to $22 \%$ in 2015 [107]. The changes are observed because of land grabbing, which has become the primary problem, especially in Bangladesh's protected forest areas during the last two decades [108]. Our study's change detection analysis suggests that changes in observed behaviour can indicate the destruction of crops due to wildlife habitat displacement and movement (e.g., occurred by elephant) or removing the agricultural field and replacing the settlements.

Among other transition events, forest to bare land to agriculture showed significant alteration between these two transition periods. Apart from land cover change detection in Bangladesh, the significant land-use changes for India's northeastern part from 2008 to 2018 were analyzed using satellite imagery [109]. It is found that the forest area had increased by $446 \mathrm{~km}^{2}$ within the last 10 years (2008-2018), and the annual rate of change was
$12 \%$. It is also demonstrated that the area under agriculture had reduced by $128 \mathrm{~km}^{2}$ with an annual decline rate of change of $2.5 \%$. The area under tea plantation declined by $307 \mathrm{~km}^{2}$ with an annual decline rate of $12 \%$, whereas the area under human settlements increased by $61 \mathrm{~km}^{2}$ with an annual decline rate of $44 \%$ [109].

There are some other factors responsible for the land cover change, for instance, shifting cultivation, which is a traditional agricultural land use (Jhum cultivation) in the Chittagong Hill Tracts (CHT) in Bangladesh. This changes over time under the influence of several internal and external pressures (e.g., intensive land-use systems, a steady increase of population, migration, the encroachment of reserve forests, etc. $[75,110]$. However, it is indicated that the fundamental causes of the shrinking forest cover in the Hill Forests in Bangladesh are: (a) own conflict among 


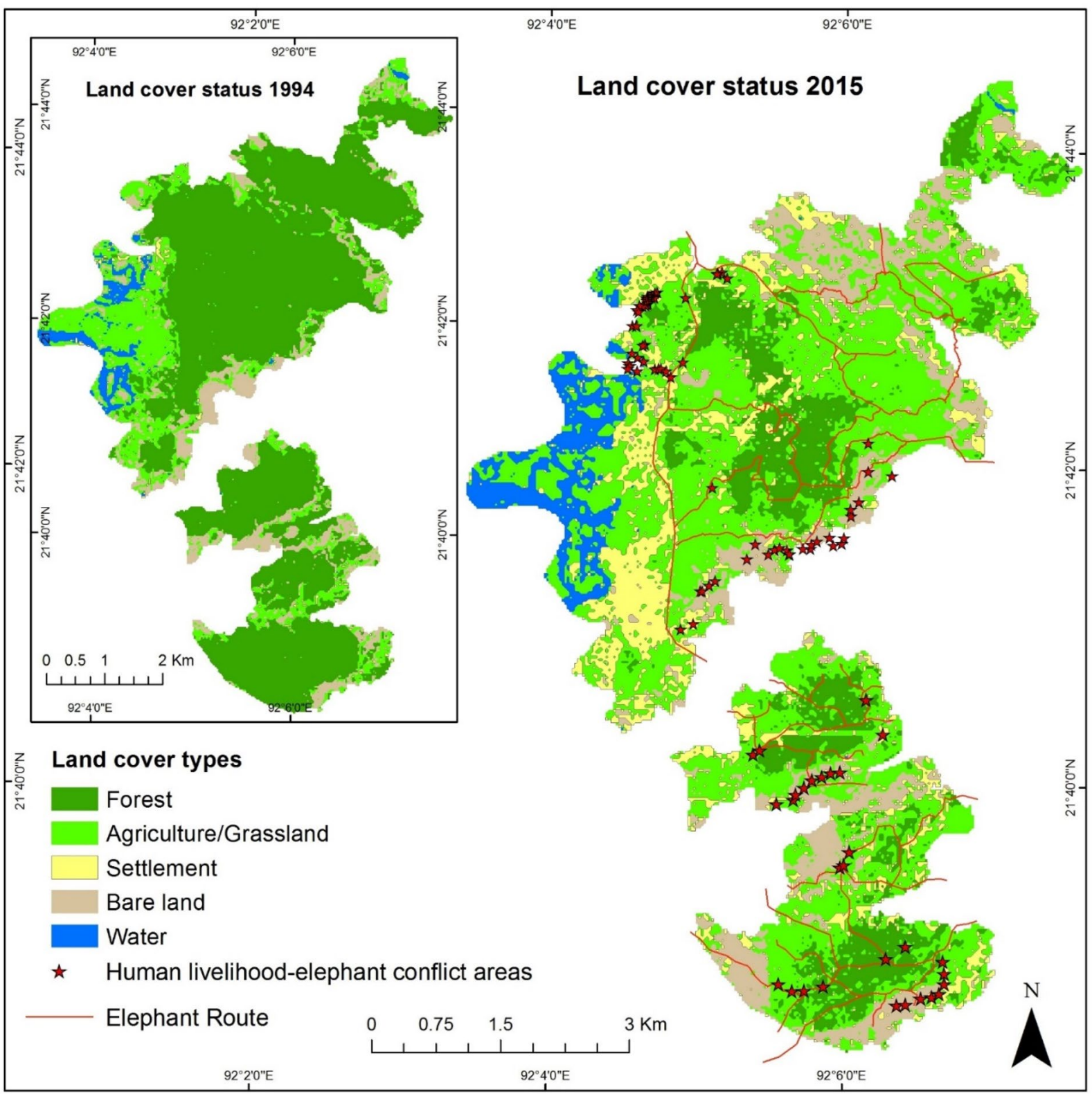

Fig. 5 Wild elephant routes

indigenous forest dwellers, (b) migrants move toward the forests, (c) unwillingness in implementing the suitable policy by forest authority are the significant causes of forest loss [61]. The improvement of the forest department's capability to operate forests sustainability remains a concern requiring a much greater government commitment. The forest department needs good cooperation from local people and the government to regulate illegal or legal cutting, over-harvesting, and encroachment, which is the most direct deforestation driver. Population migration, lack of satisfaction, aggressive behavior of the indigenous/ethnic people, challenging working situation, unsettled land tenure issue, fear apprehension from foresters, insufficient staffing, and low opportunity for foresters are the local driving factors associated with forest fragmentation, deforestation, and forest conservation and restoration. It is essential to keep in mind that individual drivers' effect on a global to local scale can change over time. For example, it is unlikely that forests in a country with internal political instability would be under the same drivers' control.

\subsection{Human-elephant conflict}

In Bangladesh, particularly in the Cox's Bazar region, humans and elephant conflict are frequent incidents [111]. 
Fig. 6 Type of affected areas by elephant observed by respondents (total number of respondents: 50)Type of affected areas by elephant observed by respondents (total number of respondents: 50 )

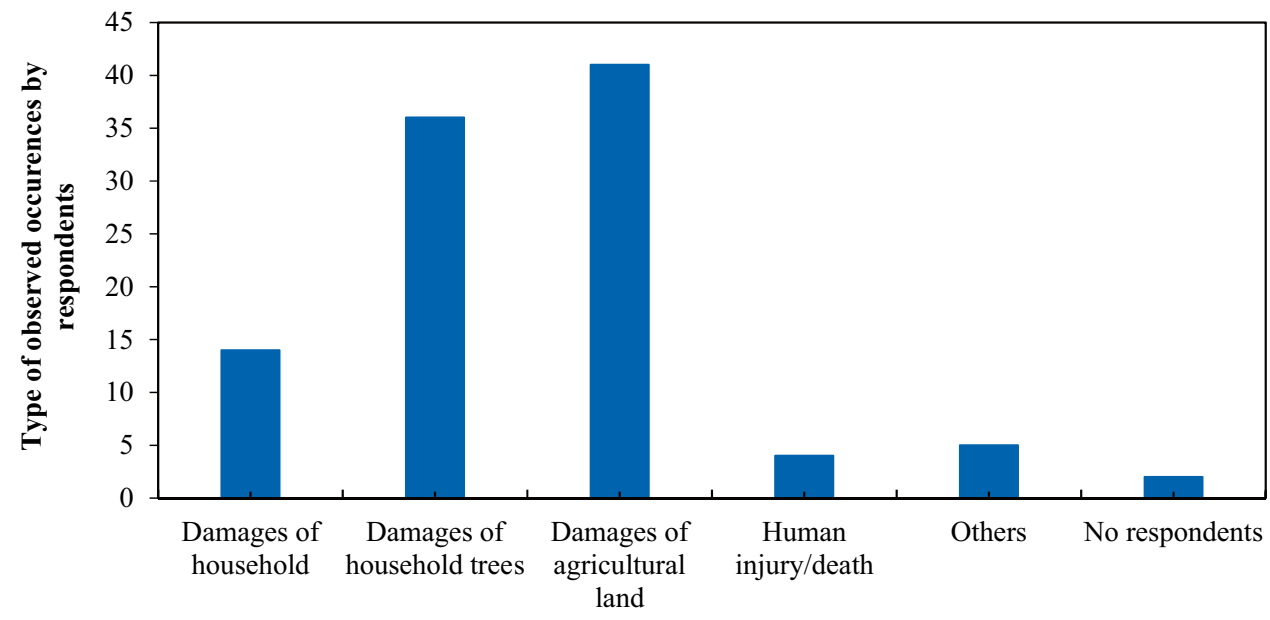

Affected areas

Fig. 7 Human-elephant conflict risk map in Fashiakhali forest reserve, Cox's Bazar. (Image source: Google Earth 2019)

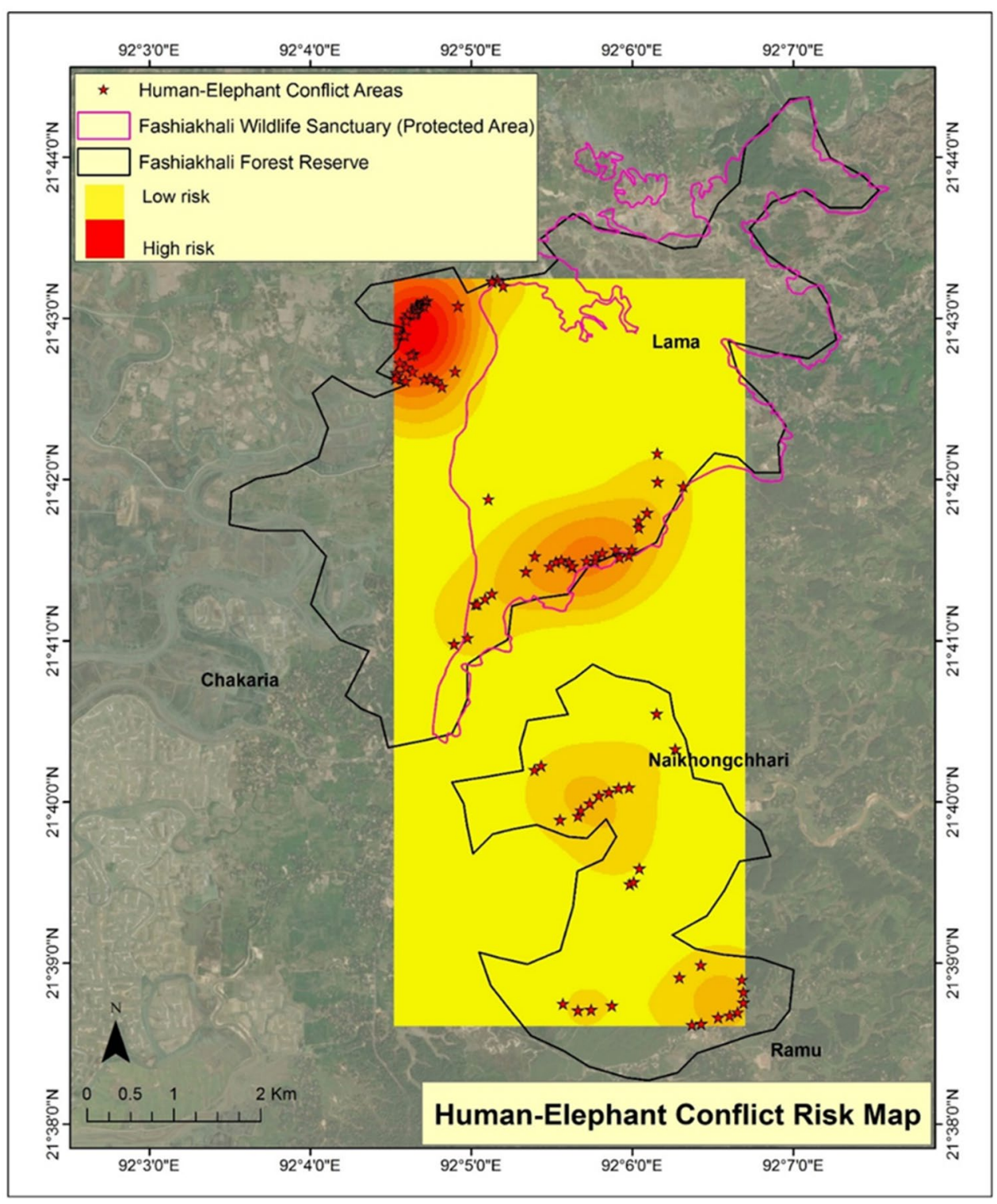


Generally, the land cover changes have more significant consequences on wild animal distribution, routes and corridors, and natural habitats, mainly known as biophysical resources [25]. Land cover changes also influence the animal's movement, e.g., obstruction of routes with the corridor. IUCN has identified Asian elephants (Elephas maximus) as endangered due to loss of habitat, elephant poaching, and human-elephant conflict [112]. Similarly, our study's land cover changes showed the impacts on the wildlife route/passage, natural habitat, and the accessibility of feeding resources for wildlife. We found a significant amount of land cover changes of the Fashiakhali forest reserve from our geospatial analysis. These land cover changes suggest an aggregate of human settlement and explain the 1994 to 2015 periods' changing situation. The land cover changes trigger the loss of wide ranges of wildlife or elephant habitat and damages of human belongings, e.g., household, trees, and agricultural fields, even social death [109]. Information acquired from the neighboring village people of Fashiakhali forest reserve also supports the argument that there is currently a higher concentration of elephant aggression on household premises. It is a clear indication of deforestation in that forested environments, and indeed, the relationship between humans and wildlife is worsening. A study from the northeastern part of India tried to show the relationship between the land-use changes and human-elephant conflicts. It demonstrated that conflicts have mostly occurred in the protected areas, tea plantations zone, and along major riverine corridors [109]. The study also revealed that the local community is often chased and stressed by the elephants in agriculture fields and at their own houses [109]. Investigating the relationship between human-wildlife and land-use change, a study conducted in Kenya, showed that agriculture expansion is considered more advantageous than pastoralism or conservation [113]. The household people around the Fashiakhali forest reserve area usually rely on the sanctuary for resources like fuelwood, grass, bamboo, and medicinal plants. Due to settlement development for refugees in the Fashiakhali, the vegetation or forested land has been diminishing. Hence, these areas are likely to become uninhabitable for elephants [114]. Besides, human actions inside and around the wildlife sanctuary result in ecosystem degradation and illegal logging in the sanctuary area [114].

\subsection{Human-wildlife conflict area analysis}

Forest protected, and the human settlements and farms usually separate reserved area boundaries from natural ecosystems people have no ecological sense to wildlife animals [115]. Consequently, the settled areas are surrounded by protected areas once inhabited by wildlife, leading to conflicts between people and wild animals [25]. From (Fig. 3), it seems that expansion of settlement and replacement of agricultural land instead of forest adjacent the protected areas increase the probability of human-elephant conflict. This map provides a scenario for the sizes needed for the management to avoid conflict. It is demonstrated that increasing agricultural land uses in the boundaries of the protected area might be the causes of this conflict reveals a similar assumption with our study [116]. Human settlements increased around every protected area, potentially increasing human activity along the edges of protected areas and threatening their ecological integrity. There is possible evidence of deforestation and shrub encroachment throughout the hot spot [116]. The conflict between humans and wildlife has been observed at several places for various human activities; for instance, evidence has been found in the Amboseli-Kilimanjaro ecosystem that has reported increased recent agricultural activities [25]. The study also demonstrated that land use for crops growing and wild and domestic animals has been reducing, setting the competition and conflict between wildlife and livestock for water forage as they live nearby [25]. Eventually, this led to wildlife predation on livestock and humans and the destruction of ranch structures by wild animals [117]. Another study observed that the human-elephant conflict is related to the land-use changes from grazing to farms and settlements. However, the changes reduce animal dispersal and migration areas and block migration routes [25].

\section{Conclusions}

This paper investigates land cover changes in Fashiakhali forest reserves in Bangladesh from 1994 to 2015 using remote sensing and GIS techniques. This study found that agricultural land and grassland are mostly affected and lost due to the increase in the settlement area by approximately $1337.9 \mathrm{ha}$. Moreover, the forest area was decreased around 1402.9 ha, which is $45.7 \%$ of the total in the study area, since it was assumed that whether there is any relationship with the biodiversity or wildlife habitats (e.g., elephant) and their impacts on the areas of human settlement and agriculture land due to changes in forested areas. The study established that there has been an expansion of agriculture and settlements into the wildlife grazing and dispersal areas. Also, human-wildlife conflicts have increased due to land use incompatibility. However, wildlife habitats are expected to further decrease significantly due to agricultural expansion. The area is well known for having elephant habitats, and the wildlife sanctuary is also crucial for biodiversity. Indeed, the evolution of human settlement adjacent to the forest areas and deforestation are the leading causes of wildlife habitat disturbances. Consequently, damages to local houses, homestead gardens, 
agricultural lands, and even social death have frequently occurred for the last few years.

Habitat destruction and fragmentation have had a significant effect on Bangladesh's wild elephant population [65]. The lack of opportunities for forest reliance on livelihoods has further exacerbated deforestation and degradation. In addition, as far as land tenure is concerned, women do not usually have land possession [118] and do not have sufficient institutional power over land even if they have access to and use many goods (e.g., firewood, non-timber forest products). Women's activities, such as conventional reforestation programs and tree plantation, can help recognize sustainable forest conservation or wildlife habitat obstacles. It may contribute to formulating appropriate and relevant governance strategies at the national and local levels. Local people and ethnic groups, particularly women and young communities, can be an insightful source of knowledge in identifying deforestation and forest destruction drivers around their communities and a platform for suitable solutions. Hence, forest management must also acknowledge the importance of inter-departmental coordination, land use planning, the significance of environmental services, and transparent land tenancy regimes to prevent forest transition, but at the same time creating a sound ecological forest management framework and not tolerating corruption within the forest. Therefore, any measures to curb this deforestation must be based on the dynamic social, political, and infrastructural changes of the rural community surrounding the forest reserve.

Acknowledgements This is a non-funded study. All authors declare that they have no conflict of interest. Mohammad Maruf Billah was mainly responsible for conceptualization, data curation and analysis, investigation, methodology, supervision, validation, visualization, writing-review and editing and critically revised the manuscript. Md. Masudur Rahman was responsible for data analysis, editing and revision of the manuscript. Joynal Abedin was responsible for drafting, editing in the methodology and revision of the manuscript and Humaira Akter was responsible for drafting and editing in the manuscript.

\section{Declarations}

Conflict of interest The authors declare that they have no conflicts of interest.

Open Access This article is licensed under a Creative Commons Attribution 4.0 International License, which permits use, sharing, adaptation, distribution and reproduction in any medium or format, as long as you give appropriate credit to the original author(s) and the source, provide a link to the Creative Commons licence, and indicate if changes were made. The images or other third party material in this article are included in the article's Creative Commons licence, unless indicated otherwise in a credit line to the material. If material is not included in the article's Creative Commons licence and your intended use is not permitted by statutory regulation or exceeds the permitted use, you will need to obtain permission directly from the copyright holder. To view a copy of this licence, visit http://creativecommons. org/licenses/by/4.0/.

\section{References}

1. Briassoulis H (2000) Analysis of land use change: theoretical and modeling approaches. Regional Research Institute, West Virginia University, Morgantown

2. Sherbinin AD (2002) A Ciesin thematic guide to land land: use and land use and land use and land-cover change (LUCC) cover change (LUCC). Center for International Earth Science Information Network (CIESIN). Columbia University, Palisades

3. Eastman JR, van Fossen M, Solo'rzano LA (2005) Transition potential modeling for land-cover change, 1 st edn. ESRI Press, Redlands

4. Rai R, Zhang Y, Paudel B, Li S, Khanal N (2017) A synthesis of studies on land use and land cover dynamics during 19302015 in Bangladesh. Sustainability 9:1866

5. Mundia CN, Aniya M (2006) Dynamics of land use/cover changes and degradation of Nairobi City, Kenya. Land Degrad Dev 17(1):97-108

6. Jat MK, Garg PK, Khare D (2008) Monitoring and modeling of urban sprawl using remote sensing and GIS techniques. Int J Appl Earth Obs Geoinf 10(1):26-43

7. Li X, Yeh AG-O (2000) Modelling sustainable urban development by the integration of constrained cellular automata and GIS. Int J Geogr Inform Tion Sci 14:131-152

8. Lopez E, Bocco G, Mendoza M, Duhau E (2001) Predicting land cover and land use change in the urban fringe a case in Morelia City, Mexico. Landsc Urban Plan 55(4):271-285

9. Seto KC, Fragkias M, Guneralp B, Reilly MK (2011) A MetaAnalysis of Global Urban Land Expansion. PLoS ONE 6(8): e23777: (p1). https://doi.org/10.1371/journal.pone.0023777

10. Alphan $\mathrm{H}$ (2003) Land use change and urbanization in Adana, Turkey. Land Degrad Dev 14(6):575-586

11. Dewan AM, Yamaguchi Y (2009b) Land use and land cover change in Greater Dhaka, Bangladesh: Using remote sensing to promote sustainable urbanization. Appl Geogr 390-401. https://doi.org/10.1016/j.apgeog.2008.12.005

12. Shalaby A, Tateishi R (2007) Remote sensing and GIS for mapping and monitoring land cover and land use changes in the Northwestern coastal zone of Egypt. Appl Geogr 27(1):28-41

13. Ali AMS (2006) Rice to shrimp: land use/land covers changes and soil degradation in southwestern Bangladesh. Land Use Policy 23(4):421-435

14. Abduallah SA, Nakagoshi $\mathrm{N}$ (2006) Changes in landscape spatial pattern in the highly developing state of Selangor, Peninsular Malaysia. Landsc Urban Plan 77(3):263-275

15. UN-REDD Bangladesh National Program (2016) Drivers of deforestation and forest degradation in Bangladesh: Final report. UN-REDD Bangladesh National Program, 10 January 2017

16. Government of Bangladesh (2014) Forest resources assessment: country report, 2015. Rome, Italy

17. Iftekhar MS (2006) Forestry in Bangladesh: an overview. J Forest 104(3):148-153

18. Alam M, Furukawa Y, Sarker SK, Ahmed R (2008) Sustainability of Sal (Shorea robusta) forest in Bangladesh: past, present and future actions. Int For Rev 10(1):29-37

19. Islam KK, Sato M (2012) Deforestation, land conversion and illegal logging in Bangladesh: the case of the Sal (Shorea robusta) forests. iForest 5: 171-178 
20. Reddy CS, Pasha SV, Jha CS, Diwakar PG, Dadhwal VK (2016) Development of national database on long-term deforestation (1930-2014) in Bangladesh. Glob Planet Change 139:173-182

21. World Wildlife Fund (2020) Forest habitat. https://www.world wildlife.org/habitats/forest-habitat. Accessed 21 July 2020

22. FAO (2011) International year of forests 2011. http://www.fao. org/forestry/iyf2011/69186/en/. Accessed 15 Dec 2019

23. Byron N, Arnold M (1999) What futures the people of the tropical forests? World Dev 27(5):789-805

24. Frimpong A (2011) Application of remote sensing and GIS for forest cver change detection. (A case study of Owabi Catchment in Kumasi, Ghana). Thesis (BSc). Kwame Nkrumah University of Science and Technology

25. Noe C (2003) The dynamics of land use changes and their impacts on the wildlife corridor between Mt. Kilimanjaro and Amboseli National Park, Tanzania. LUCID Project. International Livestock Research Institute. Nairobi, Kenya, p 31

26. Munthalia KG, Murayama Y (2011) Land use/cover change detection and analysis for Dzalanyama forest reserve, Lilongwe, Malawi. Procedia Soc Behav SciProcedia Soc Behav Sci 21:203211. https://doi.org/10.1016/j.sbspro.2011.07.035

27. Ogutu JO, Owen-Smith N, Piepho H, Kuloba B, Edebe J (2012) Dynamics of ungulates in relation to climatic and land use changes in an insularized African savanna ecosystem. Biodivers Conserv 21(4):1033-1053

28. Reeves MF, Vivien MM (2015) Modelling drivers of forest cover change in the Santchou wildlife reserve, west Cameroon using remote sensing and land use dynamic degree indexes. Can J Trop Geogr (online) 2(2):29-42

29. Seto KC, Woodcock CE, Song C, Huang X, Lu J, Kaufmann RK (2002) Monitoring land use change in the Pearl River Delta using Landsat TM. Int J Remote Sen 23(10):1985-2004

30. Reis S (2008) Analyzing land use/land cover changes using remote sensing and GIS in Rize, North-East Turkey. Sensors 8:6188-6202. https://doi.org/10.3390/s8106188

31. Turner IIBL (1994) Local faces, global flows: ehe role of land use and land cover in global environmental change. Land Degrad Dev 5(2):71-78. https://doi.org/10.1002/ldr.3400050204

32. Feddema JJ, Oleson KW, Bonan GB, Mearns LO, Buja LE, Meehl GA (2005) The importance of land-cover change in simulating future climates. Science 310:1674-1678

33. Gibbs HK, Salmon JM (2015) Mapping the world's degraded lands. Appl Geogr 57:12-21

34. Gounaridis D, Symeonakis E, Chorianopoulos I, Koukoulas S (2018) Incorporating density in spatiotemporal land use/ cover change patterns: the case of Attica, Greece. Remote Sens 10:1034. https://doi.org/10.3390/rs10071034

35. Lesschen JP, Verburg PH, Staal SJ (2005) Statistical methods for analyzing the spatial dimension of changes in land use and farming systems. The International Livestock Research Institute, Nairobi, Kenya and LUCC Focus 3 Office. Wageningen University, Netherlands

36. Djeukam R (2012) The wildlife law as a tool for protecting threatened species in Cameroon, Yaounde. Department of Wildlife and Protected Area, Ministry of Forestry and Wildlife, Cameroon

37. Mace GM (2014) Whose conservation? Science, 345:1558-1560

38. IUCN (2005) Benefits Beyond Boundaries. Pages IX-306. International Union for the Conservation of Nature. Gland, Switzerland \& Cambridge, UK

39. Distefano E (2005) Human-Wildlife Conflict worldwide: collection of case studies, analysis of management strategies and good practices. Food and Agricultural Organization of the United Nations (FAO), Sustainable Agriculture and Rural Development Initiative (SARDI), Rome, Italy. Available from:
FAO Corporate Document repository. http://www.fao.org/ documents. Accessed 01 Dec 2020

40. Brandon RB (2001) Mapping rural land use and land cover change in Carroll County, Arkansas Utilizing Multi-Temporal Landsat Thematic Mapper Satellite Imagery. Thesis. University of Arkansas. http://www.cast.uark.edu/local/brandon_thesis/ index.html. Accessed 01 Dec 2020

41. Geist HJ, Lambin EF (2002) Proximate causes and underlying driving forces of tropical deforestation. Bioscience 52:143-150

42. Lambin EF (1997) Modeling and monitoring land-cover change processes in tropical regions. Prog Phys Geogr 21(3):375-393

43. Dewan AM, Yamaguchi Y (2009a) Using remote sensing and GIS to detect and monitor land use and land cover change in Dhaka Metropolitan of Bangladesh during 1960-2005. Environ Monit Assess 150(1-4):237-249. https://doi.org/10.1007/ s10661-008-0226-5

44. Hathout $S$ (2002) The use of GIS for monitoring and predicting urban growth in East and West St Paul, Winnipeg, Manitoba, Canada. J Environ Manag 66:229-238

45. Herold M, Goldstein NC, Clarke KC (2003) The spatiotemporal form of urban growth: measurement, analysis and modeling. Remote Sens Environ 86:286-302

46. Lambin EF, Geist HJ, Lepers E (2003) Dynamics of land use and cover change in tropical regions. Annu Rev Environ Resour 28:205-241

47. Serra P, Pons X, Sauri D (2008) Land-cover and land-use change in a Mediterranean landscape: a spatial analysis of driving forces integrating biophysical and human factors. Appl Geogr 28:189-209

48. Le Hégarat-Mascle S, Ottlé C, Guérin C (2005) Land cover change detection at coarse spatial scales based on iterative estimation and previous state information. Remote Sens Environ 95:464-479

49. Mallick J, Kant Y, Bharath BD (2008) Estimation of land surface temperature over Delhi using Landsat-7 ETM+. J Ind Geophys Union 12(3):131-140

50. Raghuvanshi TK, Negassa L, Kala PM (2015) GIS based Grid overlay method versus modeling approach-a comparative study for landslide hazard zonation (LHZ) in Meta Robi District of West Showa Zone in Ethiopia. Egypt J Remote Sens Space Sci 18(2):235-250

51. Nguyen DT, Iskandar I, Ho S (2016) Land cover change and the $\mathrm{CO}_{2}$ stock in the Palembang City, Indonesia: a study using remote sensing, GIS technique and LUMENs. Egypt J Remote Sens Space Sci 19(2):313-321. https://doi.org/10.1016/j.ejrs. 2016.08.004

52. Ramachandra TV, Setturu B, Rajan KS, Chandran S, M.D (2016) Stimulus of developmental projects to landscape dynamics in Uttara Kannada, Central Western Ghats. Egypt J Remote Sens Space Sci 19(2):175-193

53. Dewan AM, Yamaguchi Y, Rahman MZ (2012) Dynamics of land use/cover changes and the analysis of landscape fragmentation in Dhaka Metropolitan, Bangladesh. GeoJournal 77:315-330. https://doi.org/10.1007/s10708-010-9399-x

54. Rahman MM (2013) Temporal change detection of vegetation coverage in Patuakhali Coastal Area of Bangladesh using GIS \& remotely sensed data. Int J Geomat Geosci 4:36-46

55. Hossain MK, Pasha MK (2004) An account of exotic flora of Bangladesh. J For Environ 2:99-115

56. Akhtaruzzaman AFM (2012) Arannayk foundation. https:// www.arannayk.org/pdf/evaluation_reports/jahangirnagar_ university.pdf. Accessed 20 Dec 2020

57. Dudley N (ed) (2008) Guidelines for applying protected area management categories. Gland, Switzerland 
58. Ahsan MM, Aziz N, Morshed HM (2016) Assessment of management effectiveness of protected areas of Bangladesh. SRCWP Project. Bangladesh Forest Department. ISBN: 9789843423931

59. Nishorgo Co-Management committee contribution (2009) Fashiakhali wildlife sanctuary. http://nishorgo.org/wp-conte nt/uploads/2017/06/7-7-6-Fashiakhali-Wildlife-Sanctuary.pdf. Accessed 01 Dec 2020

60. Sarker AHMR, Eivin S (2010) Human-wildlife conflicts and management options in Bangladesh, with special reference to Asian elephants (Elephas maximus). Int J Biodivers Sci Ecosyst Serv Manag 6(3):164-175. https://doi.org/10.1080/21513732.2011. 554867

61. Salam MA, Noguchi T, Koike M (1999) The causes of forest cover loss in the hill forests in Bangladesh. GeoJournal 47:539-549

62. Hoare R (2000) African elephants and humans in conflict: the outlook for co-existence. Oryx 34:34-38

63. MoEF (Ministry of Environment and Forests) (2011) Wildlife (Conservation) Act (Draft). MoEF, Government of the People's Republic of Bangladesh, Dhaka

64. Islam K, Jashimuddin M, Nath B, Nath TK (2016) Quantitative assessment of land cover change using landsat time series data: case of Chunati wildlife Sanctuary (CWS), Bangladesh. SSRN Electron J 3(2):45-55. https://doi.org/10.2139/ssrn.28197 64

65. Islam MA (2006) Conservation of the Asian elephants in Bangladesh. Gajah 25:21-26

66. Sarker AHMR, Røskaft E (2010) Human attitudes towards conservation of Asian elephants (Elephas maximus) in Bangladesh. Int J Biodivers Conserv 2:316-327

67. Rahman MF, Jashimuddin M, Islam K, Nath TK (2016) Land use change and forest fragmentation analysis: a geoinformatics approach on Chunati wildlife Sanctuary, Bangladesh. J Civil Eng Environ Sci 2(1):020-029. https://doi.org/10.17352/2455-488X. 000010

68. Abedin J, Billah MM, Akter H (2018) The socio-economic status and land use pattern: a micro-level analysis in Bangladesh. Int J Sci Basic Appl Res (IJSBAR) 42(3):185-194

69. Uddin MZ, Alam MF, Rahman ASMM, Hassan MA (2011) Plant biodiversity of Fashiakhali Wildlife Sanctuary, Bangladesh. In: First Bangladesh Forestry congress proceeding, pp 129-141

70. Uddin MM, Misbahuzzaman K (2007) Tree diversity in Dulhazara Safari park of Bangladesh. Malay Appli Biol 36:(2):33-40

71. Forest Department (2012) State of protected areas of Bangladesh. http://nishorgo.org/wp-content/uploads/2017/02/5-43NN-SOPA-_-FD-2012.pdf. Accessed 01 Dec 2020

72. Banglapedia (2014) Chakaria Upazila. Banglapedia: National Encyclopedia of Bangladesh. Asiatic Society of Bangladesh, Dhaka, Bangladesh. http://en.banglapedia.org/index.php? title=Chakaria_Upazila. Accessed 01 Dec 2020

73. BBS (2001) Bangladesh Bureau of Statistics; Cultural survey report of Chakaria Upazila 2007

74. Khan MS (1990) The flora of Chunati wildlife sanctuary: a preliminary survey report. National Resource Information Center, Bangladesh, pp31

75. Thapa GB, Rasul G (2006) Implications of changing national policies on land use in the Chittagong Hill Tracts of Bangladesh. J Environ Manage 81(4):441-453. https://doi.org/10.1016/j. jenvman.2005.12.002

76. Manandhar R, Odeh IOA, Ancev T (2009) Improving the accuracy of land use and land cover classification of landsat data using post-classification enhancement. Remote Sens 1:330-344

77. Traore A, Mawenda J, Komba AW (2018) Land-cover change analysis and simulation in Conakry (Guinea), using hybrid cellular-automata and Markov model. Urban Sci 2:39. https:// doi.org/10.3390/urbansci2020039

78. EGIS/WARPO (1996) Datum and map projections for GIS and GPS applications in Bangladesh (Technical Note 10). Water Resources Planning Organization, Bangladesh

79. Markham BL, Goward S, Arvidson T, Barsi J, Scaramuzza P (2006) Landsat-7 long-term acquisition plan radiometry-Evolution over time. Photogrammetric Engineering Remote Sensing 72:1129-1135

80. Roy DP, Wulder MA, Loveland TR, Woodcock CE, Allen RG, Anderson MC et al (2014) Landsat-8: science and product vision for terrestrial global change research. Remote Sens Environ 145:154-172. https://doi.org/10.1016/j.rse.2014.02.001

81. Chander G, Markham BL, Helder DL (2009) Summary of current radiometric calibration coefficients for Landsat MSS, TM, ETM+, and EO-1 ALI sensors. Remote Sens Environ 113:893-903

82. Roy DP, Ju J, Kline K, Scaramuzza PL, Kovalskyy V, Hansen M, Loveland TR, Vermote E, Zhang C (2010) Web-enabled Landsat Data (WELD): Landsat ETM + composited mosaics of the conterminous United States. Remote Sens Environ 114(1):35-49. https://doi.org/10.1016/j.rse.2009.08.011

83. Lu D, Weng Q (2007) A survey of image classification methods and techniques for improving classification performance. Int J Remote Sens 28:823-870

84. Anderson R, Hardy EE, Roach JT, Witmer RE (1976) A land use and land cover classification system for use with remote sensor data. USGS Professional Paper 964, Washington, DC

85. Mondal MH (2010) Crop agriculture of Bangladesh: challenges and opportunities, BangladeshCrop agriculture of Bangladesh: challenges and opportunities, Bangladesh. J Agril Res 35(2):235-245

86. Hasan MN, Hossain MS, Bari MA, Islam MR (2013) Agricultural land availability in Bangladesh. SRDI, Dhaka

87. Hassan MM (2017) Monitoring land use/land cover change, urban growth dynamics and landscape pattern analysis in five fastest urbanized cities in Bangladesh. Remote Sens Appl Soc Environ 7:69-83. https://doi.org/10.1016/j.rsase.2017.07.001

88. Vapnik VN (2000) The nature of statistical learning theory. Springer, New York

89. Breiman L (2001) Random forests. Mach Learn 45:5-32

90. Rabby YW, Hossain MB, Abedin J (2021) Landslide susceptibility mapping in three Upazilas of Rangamati hill district Bangladesh: application and comparison of GIS-based machine learning methods. Geocarto Int. https://doi.org/10.1080/10106049. 2020.1864026

91. Youssef AM, Pradhan B, Jebur MN, El-Harbi HM (2015) Landslide susceptibility mapping using ensemble bivariate and multivariate statistical models in Fayfa area, Saudi Arabia. Environ Earth Sci 73(7):3745-3761

92. Cutler DR, Edwards TC, Beard KH, Cutler A, Hess KT (2007) Random forests for classification in ecology. Ecology 88:2783-2792

93. Hassan MM, Ash K, Abedin J, Paul BK, Southworth J (2020) A quantitative framework for analyzing spatial dynamics of flood events: a case study of super cyclone Amphan. Remote Sens 12:3454. https://doi.org/10.3390/rs12203454

94. Ahmad A, Quegan S (2013) Comparative analysis of supervised and unsupervised classification on multispectral data. Appl Math Sci 7:3681-3694

95. Li C, Wang J, Wang L, Hu L, Gong P (2014) Comparison of classification algorithms and training sample sizes in urban land classification with Landsat thematic mapper imagery. Remote Sens 6:964-983

96. Bolstad PV, Lillesand TD (1991) Photogramm Eng Remote Sens. Photogramm Eng Remote Sens 57:67-74

97. Yin Z-Y, Stewart DJ, Bullard S, MacLachlan JT (2005) Changes in urban built-up surface and population distribution 
patterns during 1986-1999: a case study of Cairo. Egypt Comput Environ Urban Syst 29:595-616

98. Yuan F, Sawaya K, Loeffelholz B, Bauer M (2005) Land cover classification and change analysis of the Twin Cities (Minnesota) metropolitan area by multi-temporal Landsat remote sensing. Remote Sens Environ 98:317-328

99. Jat MK, Garg PK, Khare D (2017) Modelling of urban growth using spatial analysis techniques: a case study of Ajmer City (India). Int J Remote Sens 29(2):143-1161

100. Jensen IR, Ramsey EW (1987) Inland wetland change detection using Aircraft MSS data. Photogramm Eng Remote Sens 53(5):521-529

101. Harris PM, Ventura SJ (1995) The integration of geographic data with remotely sensed imagery to improve classification in an urban area. Photogramm Eng Remote Sens 61(8):993-998

102. Abedin J, Rabby YW, Hasan I, Aktar H (2020) An investigation of the characteristics, causes, and consequences of June 13, 2017, landslides in Rangamati District Bangladesh. Geoenviron Disasters 7:23. https://doi.org/10.1186/s40677-020-00161-z

103. Lillesand TM, Kiefer RW (1999) Remote sensing and image interpretation. Willey, New York

104. Jensen JR (1996) Introductory digital image processing: a remote sensing perspective. Prentice-Hall, Upper Saddle

105. Rosenfield GH, Fitzpatrick-Lins K (1986) A coefficient of agreement as a measure of thematic classification accuracy. Photogrammetric Engineering Remote Sensing 52(2):223-227

106. Hassan MM, Smith AC, Walker K, Rahman MK, Southworth J (2018) Rohingya refugee crisis and forest cover change in Teknaf, Bangladesh. Remote Sens 10:689. https://doi.org/10. 3390/rs1005068

107. Islam K, Rahman MF, Jashimuddin M (2018) Modelling land use change using cellular automata and artificial neural network: the case of Chunati Wildlife Sanctuary, Bangladesh. Ecol Ind 88:439-453. https://doi.org/10.1016/j.ecolind.2018.01.047 ISSN 1470-160X

108. Masum KM, Mansor A, Islam MN, Saha N, Hasan MZ, Mansor A (2016) Assessment of land grabbing from protected forest areas of Bhawal National Park in Bangladesh. Landsc Res. https://doi.org/10.1080/01426397.2015.1078456

109. Naha D, Sathyakumar S, Dash S, Chettri A, Rawat GS (2019) Assessment and prediction of spatial patterns of humanelephant conflicts in changing land cover scenarios of a human-dominated landscape in North Bengal. PLOS ONE 14(2):e0210580

110. Rasul G, Thapa GB, Zoebisch MA (2004) Determinants of landuse changes in the Chittagong Hill Tracts of Bangladesh. Appl Geogr 24(3):217-240. https://doi.org/10.1016/j.apgeog.2004. 03.004

111. Wahed MA, Ullah MR, Irfanullah HM (2016) Human-elephant conflict mitigation measures: lessons from Bangladesh. IUCN, International Union for Conservation of Nature, Bangladesh Country Office, Dhaka, Bangladesh. ISBN: 978-984-34-1219-5

112. Choudhury A, Lahiri Choudhury DK, Desai A, Duckworth JW, Easa PS, Johnsingh AJT, Fernando P, Hedges S, Gunawardena $M$, Kurt F, Karanth U, Lister A, Menon V, Riddle H, Rubel A, Wikramanayake E (2008) Elephas maximus. The IUCN Red List of Threatened Species 2008: e.T7140A12828813. https://doi. org/10.2305/IUCN.UK.2008.RLTS.T7140A12828813.en

113. Okello MM (2005) Land use changes and human-wildlife conflicts in the Amboseli Area, Kenya. Hum Dimens Wildl 10(1):1928. https://doi.org/10.1080/10871200590904851

114. IRG (International Resource Group) (2012) Integrated protected area co-management (IPAC), State of Bangladesh's Forest Protected Areas 2010. http://nishorgo.org/wp-content/uploads/ 2017/02/5-43-NN-SOPA_USAID.pdf. Accessed 01 Dec 2020

115. Nahonyo C (2001) Human Elephant Conflicts in the Greater Ruaha ecosystem, Tanzania. Thesis (PhD). Durrell Institute of Conservation and Ecology, University of Kent at Canterbury

116. Bailey KM, McCleery RA, Binford MW, Zweig C (2015) Landcover change within and around protected areas in a biodiversity hotspot. J Land Use Sci. https://doi.org/10.1080/17474 23X.2015.1086905

117. Kimanzi JK, Wishitemi BEL (2003) Effect of land use/cover changes on wildlife depredation in Masai Mara ecosystem. Int J Environ Stud 60(5):453-461. https://doi.org/10.1080/00207 23022000026310

118. International Labour Organization (2014) A quiet revolution: Women in Bangladesh. http://www.ilo.org/global/about-theilo/newsroom/comment-analysis/WCMS_234670/lang--en/ index.htm. Accessed 01 Dec 2020

Publisher's Note Springer Nature remains neutral with regard to jurisdictional claims in published maps and institutional affiliations. 